\title{
Differential expression of peroxisome proliferator-activated receptor delta at implantation sites and in decidual cells of rat uterus
}

\author{
N-Z. Ding ${ }^{1}, X-H . M^{1,2}, H-L . D^{1}{ }^{1}$, L-B. Xu ${ }^{1}$ and Z-M. Yang ${ }^{1 *}$ \\ ${ }^{1}$ College of Life Sciences, Northeast Agricultural University, Harbin 150030, People's Republic of China; \\ and ${ }^{2}$ National Key Laboratory of Contraceptive Drugs and Devices, Shanghai Institute of Planned \\ Parenthood Research, Shanghai 200032, People's Republic of China
}

The aim of this study was to examine the expression and regulation of peroxisome proliferator-activated receptor delta (PPARס) gene in rat uterus during early pregnancy by in situ hybridization and immunohistochemistry. PPAR $\delta$ mRNA expression in the luminal epithelium was high on day 1 of pregnancy, gradually declined from day 2 and was undetectable on day 5 of pregnancy. However, expression in the glandular epithelium began to increase from day 2 and was high on day 5 of pregnancy. There was no detectable PPARס immunostaining in the luminal and glandular epithelium from day 1 to day 5 . On day 6 of pregnancy when embryos implanted, PPARס mRNA and immunostaining were intense in the subluminal stroma at implantation sites. On days 7 and 8, there was strong expression of both PPAR $\delta$ mRNA and intense immunostaining in the decidualized area near the lumen. There was low expression of PPARס in the subluminal stroma and glandular epithelium under delayed implantation. After delayed implantation was terminated by oestrogen treatment and embryo implantation was initiated, both PPARס mRNA and immunostaining were strongly induced in the subluminal stroma. Intense PPARס immunostaining was observed in the decidua under artificial decidualization, while no detectable immunostaining was seen in the uninjected control horn. Retinoid $X$ receptor $(\mathbf{R X R} \alpha)$ immunostaining was seen in the subluminal stroma surrounding the implanting blastocyst on day 6 and in the decidual cells on days 7 and 8 of pregnancy. In conclusion, the high PPAR $\delta$ expression at implantation sites and in the decidual cells in rat uterus indicates that PPARס may play an important role during implantation and decidualization.

\section{Introduction}

Peroxisome proliferator-activated receptors (PPARs) are members of the nuclear hormone receptor superfamily of ligand-dependent transcription factors. Three PPAR isoforms, PPAR $\alpha$, PPARס (also known as PPAR $\beta$ ) and PPAR $\gamma$, have been cloned in mice (Guan and Breyer, 2001). PPARs must heterodimerize with retinoid $X$ receptors (RXRs) which function as promiscuous partners for various nuclear receptorsduring transcriptional regulation (Kliewer et al., 1992). Although PPAR $\alpha$ and PPAR $\gamma$ have been studied extensively, much less is known about

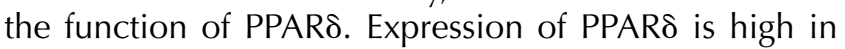
brain, colon and skin, and PPAR $\delta$ may be involved in bone formation, lipid metabolism and epidermal maturation (Matsuura et al., 1999; Mano et al., 2000). PPARס deficiency in mice results in placental defects and frequent (>90\%) mid-gestation lethality, and also a marked reduction in adiposity relative to wild-type levels (Barak et al., 2002). In COX-2-deficient mice, there are failures

*Correspondence

Email: zmyang@mail.neau.edu.cn in implantation and decidualization (Lim et al., 1997). L-165,041, a PPAR $\delta$-selective agonist, is able to restore implantation in COX-2 deficient mice. Furthermore, the co-administration of L-165,041 with 9-cis-retinoic acid, an RXR agonist, greatly improved implantation rate in COX2 $2^{-1-}$ recipients. PPAR $\delta$ is also highly expressed in mouse uterus at the implantation site (Lim et al., 1999).

The aim of the present study was to determine whether PPARS is essential for embryo implantation in mammalian species other than mice. In situ hybridization and immunohistochemistry were used to examine the expression of PPARS gene in rat uterus during early pregnancy and pseudopregnancy, delayed implantation and artificial decidualization, and also its regulation by steroid hormones. In addition, RXR $\alpha$ immunostaining during early pregnancy was performed as PPAR $\delta$ functions as a heterodimer with RXR $\alpha$.

\section{Materials and Methods}

\section{Animals and treatments}

Mature rats (Sprague-Dawley strain) were caged in a controlled environment (14 h light:10 h dark). All animal 
procedures were approved by the Institutional Animal Care and Use Committee of Northeast Agricultural University. The stage of the oestrous cycle was determined by inspection of vaginal smears. Adult females were mated with fertile males of the same strain. Pregnancy was confirmed by the presence of spermatozoa in vaginal smear (day $1=$ first day of vaginal sperm-positive result). Pregnancy on days 1-5 was confirmed by flushing embryos from the reproductive tracts. The implantation sites on days 6-7 were identified by i.v. injection of $0.1 \mathrm{ml}$ of $1 \%(\mathrm{w} / \mathrm{v})$ Chicago blue solution in $0.85 \%(\mathrm{w} / \mathrm{v})$ $\mathrm{NaCl}$. Pseudopregnancy was induced by keeping adult females in cages with vasectomized males and confirmed by checking for a vaginal plug (either in the vagina or on the cage floor) next morning. At least three rats were used in each stage or treatment in this study.

Delayed implantation was induced by treating the pregnant rats on day 4 of pregnancy with progesterone (5 $\mathrm{mg}$ per rat, s.c.) and the rats were then ovariectomized at $08.30-09.00 \mathrm{~h}$. Progesterone (5 mg per rat) was injected to maintain delayed implantation from day 5 to day 7. The progesterone-primed delayed-implantation rats were treated with oestradiol (250 ng per rat) to terminate delayed implantation. The rats were killed by stunning and cervical dislocation and uteri were collected $24 \mathrm{~h}$ after oestrogen treatment. The implantation sites were identified by i.v. injection of $1 \%$ Chicago blue solution into the tail.

\section{Artificial decidualization}

Mature female rats were ovariectomized and after 5 days were sensitized for the decidual cell reaction according to the procedures described by Kennedy and Ross (1997). Some of the rats were given bilateral intrauterine injection of $100 \mu \mathrm{l}$ of sesame oil at about $12.00 \mathrm{~h}$ on the equivalent of day 5 of pseudopregnancy. The animals that did not receive the intrauterine injection served as non-stimulated controls (Orlando-Mathur et al., 1996). Treated rats were killed 6 days later after the intrauterine injection of oil.

\section{Immunohistochemistry}

Rat uteri were immediately fixed in Bouin's solution for $24 \mathrm{~h}$, dehydrated and embedded in paraffin wax. Sections $(7 \mu \mathrm{m})$ were cut, deparaffinized and rehydrated. Non-specific binding was blocked in $10 \%(\mathrm{v} / \mathrm{v})$ normal horse serum in PBS at $37^{\circ} \mathrm{C}$ for $1 \mathrm{~h}$. The sections were incubated with goat anti-human PPAR IgG (1:150, Santa Cruz Biotechnology, Inc., Santa Cruz, CA) or rabbit antihuman RXR $\alpha$ IgG (1:100, Santa Cruz Biotechnology) in $10 \%(\mathrm{v} / \mathrm{v})$ horse serum at $4^{\circ} \mathrm{C}$ for $16 \mathrm{~h}$. The sections were then incubated with biotinylated rabbit anti-goat IgG or biotinylated goat anti-rabbit IgG followed by a streptavidin-alkaline phosphatase complex and Vector
Red according to the manufacturer's protocol (Vectastain ABC-AP kit, Vector Laboratories, Burlingame, CA). Endogenous alkaline phosphatase activity was inhibited by adding $1 \mathrm{mmol}$ levamisole $\mathrm{I}^{-1}$ (Sigma Chemical Co., St Louis, MO) into Vector Red substrate solution. Moreover, goat anti-human PPARS was replaced with the same concentration of normal goat $\operatorname{lgG}$ as a negative control. The sections were counterstained with haematoxylin and mounted. The degree of staining was assessed subjectively by blind examination of the slides by two investigators.

\section{In situ hybridization}

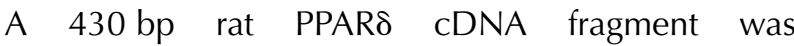
reverse-transcribed and amplified with the total RNA from rat uterus using forward primer $5^{\prime}$ GAGGAGAAAGAGGAAGTGG-3' and reverse primer 5'-CCACCAGCTTCCTCTTCTC-3' designed according to rat PPARס (295-724 bp, Genbank accession number U40064). The amplification of PPAR $\delta$ cDNA was done for $30 \mathrm{cycles}$ at $94^{\circ} \mathrm{C}$ for $30 \mathrm{~s}, 60^{\circ} \mathrm{C}$ for $30 \mathrm{~s}$ and $72{ }^{\circ} \mathrm{C}$ for $45 \mathrm{~s}$. The amplified fragment of PPAR $\delta$ was recovered from the agarose gel and cloned into pGEM-T plasmid (pGEM-T Vector System 1, Promega, Madison, $\mathrm{WI}$ ). The orientation of PPAR $\delta$ fragment in pGEM-T plasmid was determined by a combination of the primers for T7, SP6 and PPAR $\delta$. The cloned PPAR $\delta$ fragment was further verified by sequencing. These plasmids were linearized with appropriate enzymes for labelling. Digoxigenin-labelled antisense or sense cRNA probes were transcribed in vitro using a digoxigenin RNA labelling kit (T7 for sense and SP6 for antisense; Boehringer Mannheim, Mannheim).

Uteri were cut into $4-6 \mathrm{~mm}$ pieces and flash frozen in liquid nitrogen. Frozen sections $(10 \mu \mathrm{m})$ were mounted on slides coated with 3-aminopropyltriethoxy-silane (Sigma) and fixed in $4 \%(\mathrm{w} / \mathrm{v})$ paraformaldehyde solution in PBS. The sections were washed in PBS twice, treated in $1 \%(\mathrm{v} / \mathrm{v})$ Triton-100 for $20 \mathrm{~min}$ and washed again in PBS three times. After prehybridization in the solution of $50 \%(\mathrm{v} / \mathrm{v})$ formamide and $5 \times$ SSC $(1 \times$ SSC is $0.15 \mathrm{~mol}$ sodium chloride $\mathrm{I}^{-1}, 0.015$ mol sodium citrate $\mathrm{I}^{-1}$ ) at room temperature $\left(20^{\circ} \mathrm{C}\right)$ for $15 \mathrm{~min}$, the sections were hybridized in the hybridization buffer $(5 \times$ SSC, $50 \%$ $(\mathrm{v} / \mathrm{v})$ formamide, $0.02 \%(\mathrm{w} / \mathrm{v}) \mathrm{BSA}, 250 \mu \mathrm{g}$ yeast tRNA $\mathrm{ml}^{-1}, 10 \%(\mathrm{w} / \mathrm{v})$ dextran sulfate, $1 \mu \mathrm{g} \mathrm{ml}^{-1}$ denatured digoxigenin-labelled antisense or sense RNA probe for rat PPARS) at $55^{\circ} \mathrm{C}$ for $16 \mathrm{~h}$. After hybridization, the sections were washed in $50 \%(\mathrm{v} / \mathrm{v})$ formamide $/ 5 \times \mathrm{SSC}$ at $55^{\circ} \mathrm{C}$ for $15 \mathrm{~min}, 50 \%(\mathrm{v} / \mathrm{v})$ formamide $/ 2 \times \mathrm{SSC}$ at $55^{\circ} \mathrm{C}$ for $30 \mathrm{~min}, 50 \%(\mathrm{v} / \mathrm{v})$ formamide/ $0.2 \times \mathrm{SSC}$ at $55^{\circ} \mathrm{C}$ twice for $30 \mathrm{~min}$ each, and $0.2 \times \mathrm{SSC}$ at room temperature for $5 \mathrm{~min}$. After non-specific binding was blocked in $1 \%(\mathrm{w} / \mathrm{v})$ block mix (Boehringer Mannheim) for $1 \mathrm{~h}$, the sections were incubated in sheep anti-digoxigenin 
antibody conjugated with alkaline phosphatase (1:5000, Boehringer Mannheim) in $1 \%$ block mix overnight at $4{ }^{\circ} \mathrm{C}$. The signal was visualized with $0.4 \mathrm{mmol} 5$-bromo-4chloro-3-indolyl phosphate $\mathrm{I}^{-1}$ and $0.4 \mathrm{mmol}$ nitroblue tetrazolium $\mathrm{I}^{-1}$ in the buffer containing $100 \mathrm{mmol}$ Tris$\mathrm{HCl} \mathrm{I}^{-1}, \mathrm{pH} 9.5,100 \mathrm{mmol} \mathrm{NaCl} \mathrm{I}{ }^{-1}$ and $50 \mathrm{mmol}$ $\mathrm{MgCl}_{2} \mathrm{I}^{-1}$. Endogenous alkaline phosphatase activity was inhibited with $2 \mathrm{mmol}$ levamisole $\mathrm{I}^{-1}$. All of the sections were counterstained with $1 \%(\mathrm{w} / \mathrm{v})$ methyl green in 0.12 mol glacial acetic acid $\mathrm{I}^{-1}$ and $0.08 \mathrm{~mol}$ sodium acetate $\mathrm{I}^{-1}$ for $30 \mathrm{~min}$.

\section{Results}

PPAR $m R N A$ in the uterus during early pregnancy

There was high expression of PPARS mRNA in the luminal epithelium on day 1 (Fig. 1a). After digoxigeninlabelled PPAR $\delta$ antisense cRNA probe was replaced by digoxigenin-labelled PPAR $\delta$ sense cRNA probe, there was no detectable expression in the uterus on day 1 of pregnancy (Fig. 1b). Expression of PPARS mRNA in the luminal epithelium gradually declined from day 2 and was undetectable on day 5 (Fig. 1c-e). However, the expression in the glandular epithelium began to increase from day 2 and was high on day 5 (Fig. 1c-e). On day 6 when embryos implanted, a high expression was seen in the subluminal stroma at implantation sites (Fig. 1f). On days 7 and 8, PPAR $\delta$ mRNA was detected in the decidualized area near the lumen (Fig. 1g). The PPARS mRNA was mainly seen in the mesometrial side of the decidua on day 9 (Fig. 1h). Additionally, PPAR $\delta$ mRNA was detected in the embryos from days 7 to 9 (Fig. 1h).

\section{PPARS immunostaining during early pregnancy}

There was no detectable PPAR immunostaining in the luminal and glandular epithelium from day 1 to day 5 (Fig. $2 \mathrm{a}-\mathrm{c}$ ). PPAR $\delta$ immunostaining was seen in the subluminal stroma at the implantation site on day 6 (Fig. 2d). On days 7 and 8, PPAR immunostaining was observed in the decidua near the lumen and embryos (Fig. 2f-g). On day 9, PPARס immunostaining was mainly in the mesometrial side of the decidua (Fig. $2 \mathrm{~h}$ ).

\section{PPARס mRNA and immunostaining during pseudopregnancy}

There was a low expression of PPAR $\delta$ mRNA in the luminal and glandular epithelium from day 1 to day 8 of pseudopregnancy except for a considerably high expression in the luminal epithelium on day 1 (data not shown). No detectable PPARס immunostaining was seen in the luminal and glandular epithelium from day 1 to day 8 of pseudopregnancy (Fig. 2e).
Expression of PPAR $\mathrm{mRNA}$ and protein in the delayed implanting uterus before and after the initiation of implantation

There was low expression of PPAR mRNA in the subluminal stroma and glandular epithelium under delayed implantation (Fig. 3a). After delayed implantation was terminated by oestrogen treatment and embryo implantation initiated, there was high expression of PPARS mRNA in the subluminal stroma and low expression in the glandular epithelium (Fig. 3b).

There was no detectable PPAR $\delta$ immunostaining in the uterus under delayed implantation (Fig. 3c). After delayed implantation was terminated by oestrogen treatment and embryo implantation initiated, intense PPAR $\delta$ immunostaining was seen in the subluminal stroma and implanting blastocyst (Fig. 3d).

\section{PPARס immunostaining under artificial decidualization}

There was no detectable immunostaining in the uninjected control horn (Fig. 3e), whereas intense PPARס immunostaining was observed in the decidua under artificial decidualization (Fig. 3f).

\section{$R X R \alpha$ immunostaining during early pregnancy}

There was basal $R X R \alpha$ immunostaining in the uteri on days 1-5 of pregnancy (Fig. 4a-d). On day 6 when embryos implanted, $\mathrm{RXR} \alpha$ immunostaining was strong in the subluminal stroma immediately surrounding the implanting blastocyst (Fig. 4e). RXR $\alpha$ immunostaining was strongly detected in the decidua near the lumen on day 7 (Fig. 4f) and in a larger area of the decidua on day 8 (Fig. 4g), but no corresponding immunostaining was seen when rabbit anti-human $\mathrm{RXR} \alpha$ was replaced by normal rabbit IgG (Fig. 4h).

\section{Discussion}

In the present study, both PPAR $\mathrm{mRNA}$ and immunostaining were strongly detected in the subluminal stroma at the implantation site on day 6 of pregnancy in rats. However, these results were not seen on day 5 of pregnancy. High expression of PPAR $\delta$ was also reported in the subluminal stroma at implantation sites in mouse uterus (Lim et al., 1999). Furthermore, although no PPAR $\delta$ signals were observed in rat uterus under delayed implantation, both PPAR $\delta$ mRNA and immunostaining were also highly induced in the subluminal stroma at the implantation site once delayed implantation was terminated by oestrogen treatment and the embryo had implanted. Interestingly, $\mathrm{RXR} \alpha$ immunostaining was detected in the subluminal stroma at the implantation site in the rat uterus. These data showed that PPAR $\delta$ expression was specifically stimulated by the presence of active blastocysts since no corresponding signals were seen in the rat uterus on day 6 of pseudopregnancy in this study. PPAR $\delta$ may be important too for implantation 


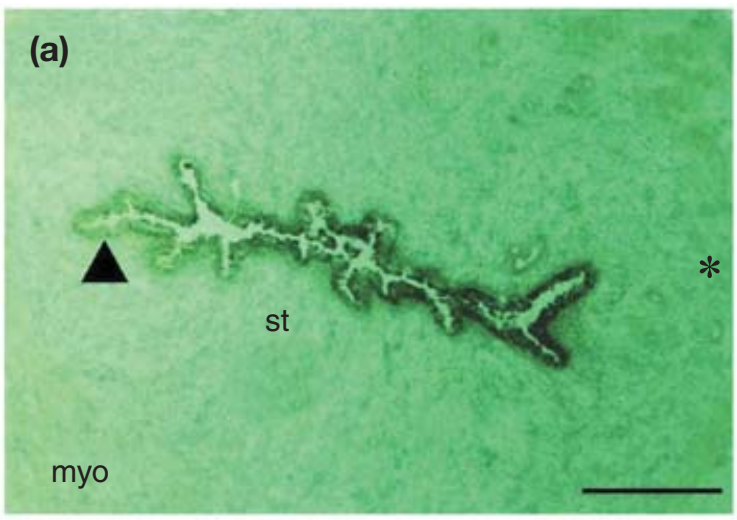

(b)
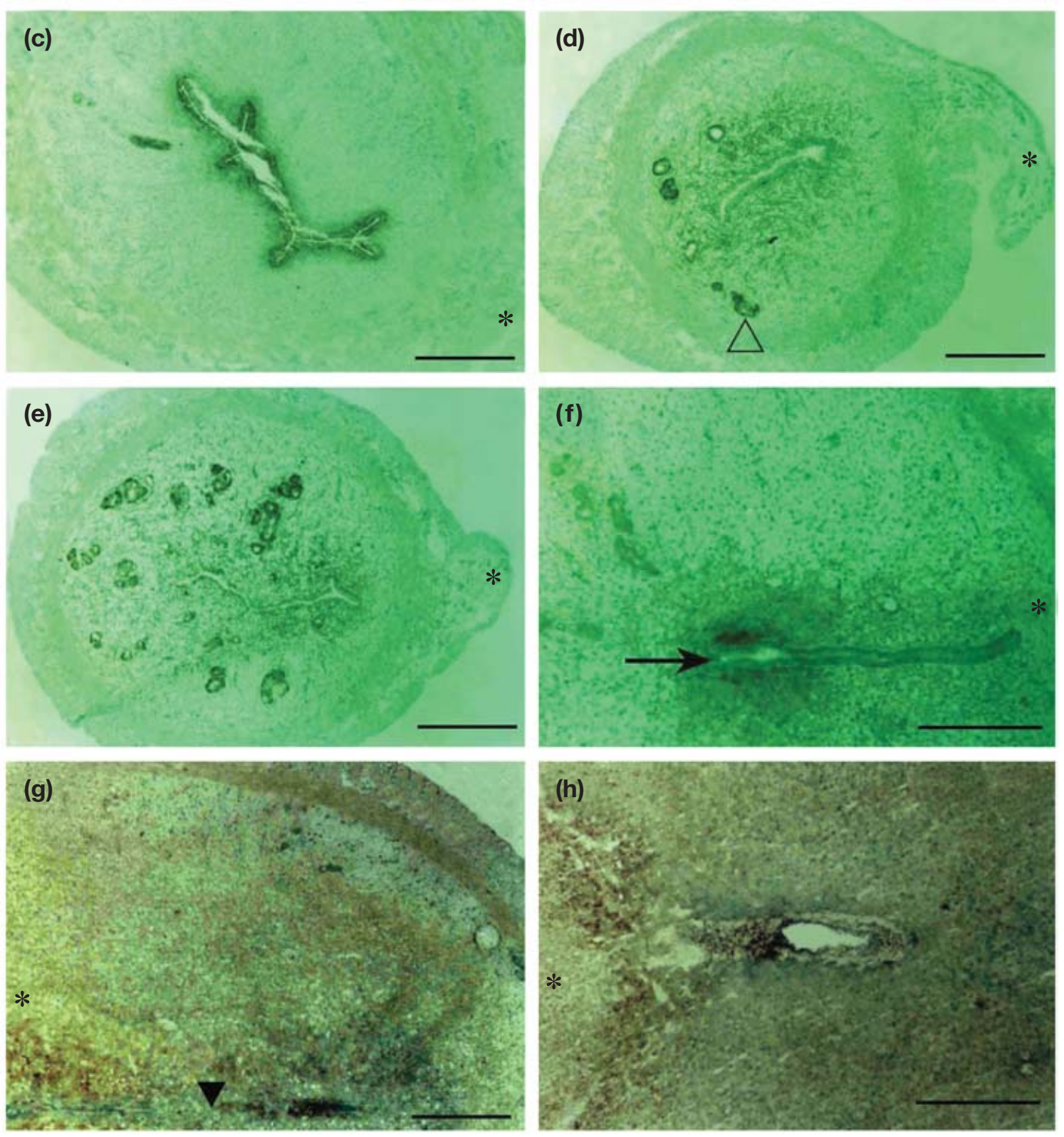

Fig. 1. In situ hybridization of peroxisome proliferator-activated receptor delta (PPAR $\delta$ ) $m R N A$ in rat uterus on days (a) 1, (c) 2, (d) 4, (e) 5, (f) 6, (g) 8 and (h) 9 of pregnancy. After digoxigenin-labelled PPAR $\delta$ sense cRNA was used for probe, no signal was seen in rat uterus on day 1 of pregnancy (b). Arrow: implanting blastocyst; $\mathbf{\Lambda}, \mathbf{\nabla}$ : luminal epithelium; $\triangle$ : glandular epithelium; st: stroma; myo: myometrium; *: mesometrial side. Scale bars represent $30 \mu \mathrm{m}$. 

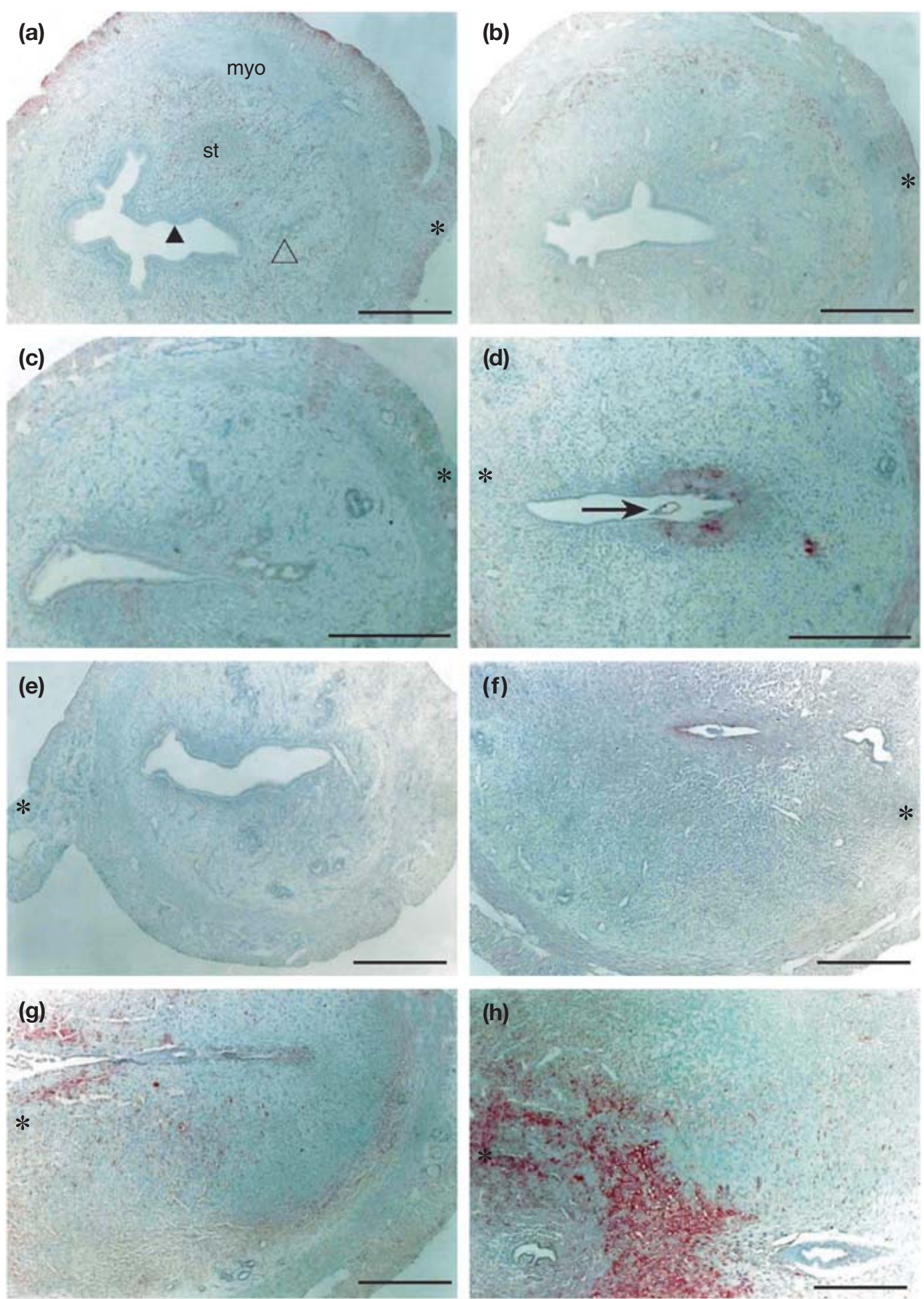

Fig. 2. Peroxisome proliferator-activated receptor delta (PPARS) immunostaining in rat uterus on days (a) 1 , (b) 4, (c) 5, (d) 6, (f) 7, (g) 8 and (h) 9 of pregnancy. There was no detectable PPAR $\delta$ immunostaining in rat uterus on day 6 of pseudopregnancy (e). Arrow: implanting blastocyst; $\mathbf{\Delta}$ : luminal epithelium; $\triangle$ : glandular epithelium; st: stroma; myo: myometrium; *: mesometrial side. Scale bars represent $30 \mu \mathrm{m}$. 

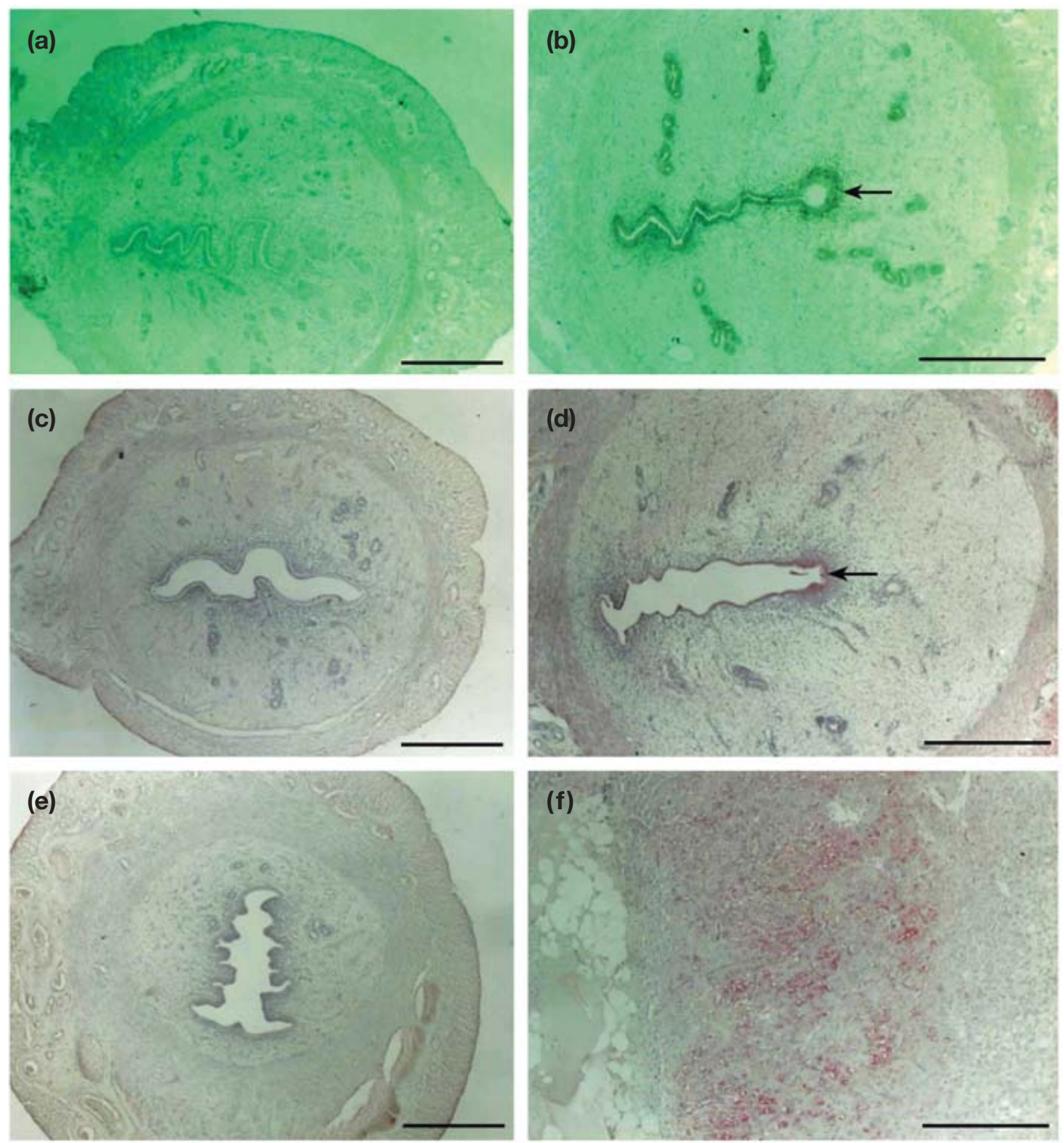

Fig. 3. No detectable peroxisome proliferator-activated receptor delta (PPARס) (a) mRNA or (c) immunostaining was observed in rat uterus during delayed implantation. After delayed implantation was terminated by oestrogen treatment and the embryo was implanted, there was strong PPAR $\delta$ mRNA expression in the subluminal stroma (b)

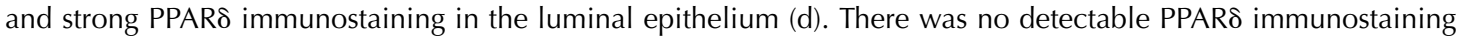
in the control uterus (e), whereas a strong PPAR $\delta$ immunostaining was observed in the decidual cells under artificial decidualization (f). Arrow: implanting blastocyst. Scale bars represent $30 \mu \mathrm{m}$.

in rats through heterodimerizing with $\mathrm{RXR} \alpha$ as in mice. In the mouse uterus, COX-2 expression was co-localized with PPAR $\delta$ at implantation sites (Chakraborty et al., 1996). As $\mathrm{PGI}_{2}$ was the most dominant prostaglandin and no $\mathrm{PGI}_{2}$ receptor (IP) expression was seen at the implantation site of mouse uterus, COX-2-derived $\mathrm{PGI}_{2}$ might mediate embryo implantation via PPARס (Lim et al., 1999). $\mathrm{PGI}_{2}$-mediated activation of PPAR $\delta$ was also reported in colorectal cancer (Gupta et al., 2000). Additionally, intracellular $\mathrm{PGI}_{2}$ formed by expressing prostacyclin synthase in human embryonic kidney 293 cells could promote apoptosis by activating endogenous

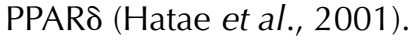

Although COX-2-deficient mice showed multiple failures in implantation and decidualization (Lim et al., 1997), the implantation in the PPAR $\delta$-deficient mice was normal (Barak et al., 2002). This finding indicates that other molecules may compensate for the loss of PPAR $\delta$. Microsomal prostaglandin E synthase was strongly expressed at the implantation site of mouse 

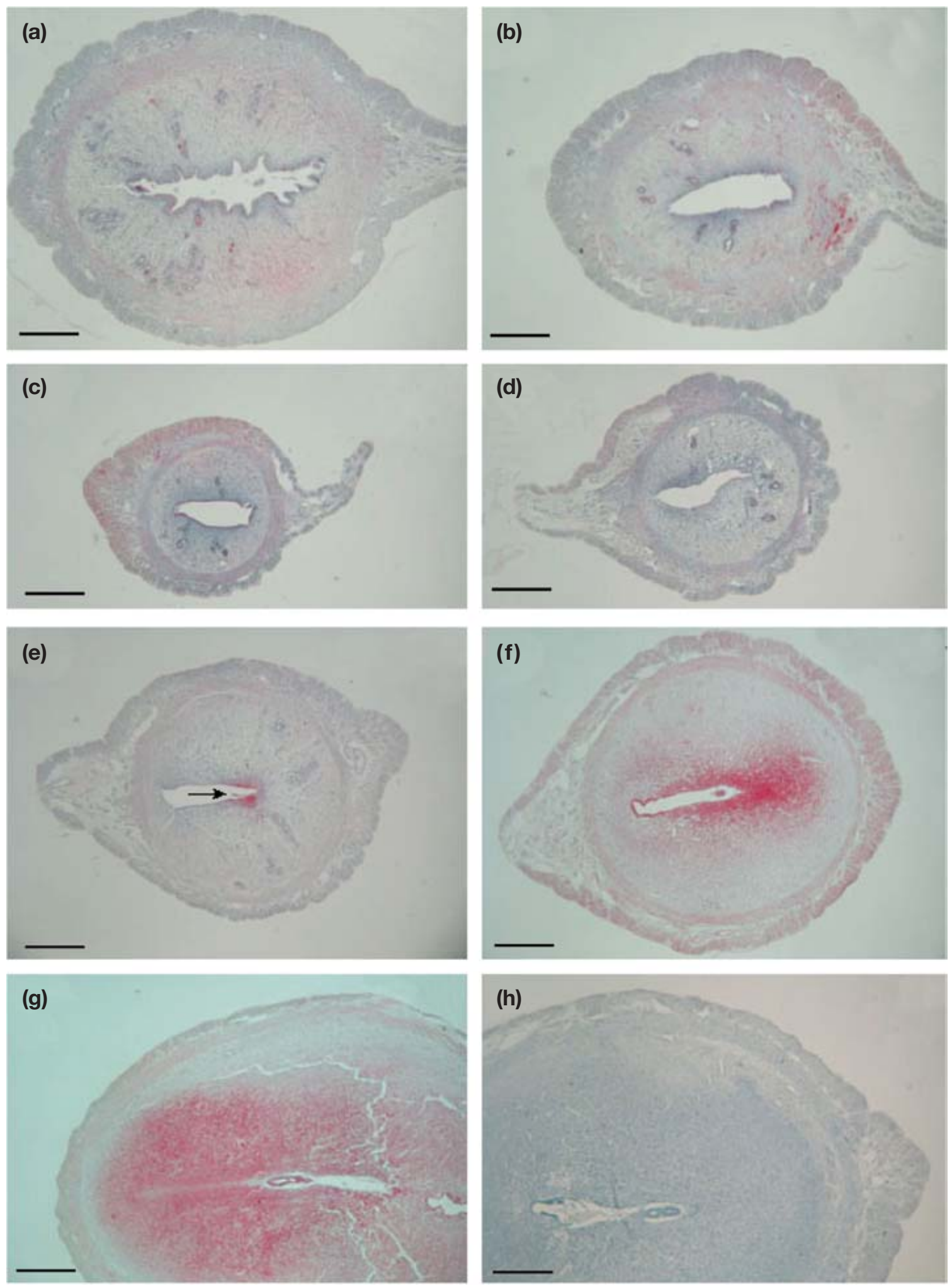

Fig. 4. Retinoid $X$ receptors $(R X R \alpha)$ immunostaining in rat uteri on days (a) 1, (b) 2, (c) 3, (d) 5, (e) 6, (f) 7 and (g) 8 of pregnancy. No immunostaining was seen in rat uterus on day 8 of pregnancy when rabbit anti-human $\operatorname{RXR} \alpha$ antibody was replaced with normal rabbit IgG (h). Scale bars represent $30 \mu \mathrm{m}$. 
uterus ( $\mathrm{Ni}$ et al., 2002). EP2, a subtype of $\mathrm{PGE}_{2}$ receptor, was also highly expressed at implantation sites (Lim and Dey, 1997). It is possible that $\mathrm{PGE}_{2}$ may compensate for the loss of PPAR $\delta$ and mediate embryo implantation. However, $\mathrm{PGE}_{2}$ was able partially to restore implantation in COX-2-deficient mice, whereas COX2-derived prostacyclin $\left(\mathrm{PGI}_{2}\right)$ or PPAR $\delta$ agonists greatly improved the implantation in these deficient mice (Lim et al., 1999).

PPAR $\delta$ expression was also detected in the decidua on days 7-9 of pregnancy in rat uterus. As intense PPAR $\delta$ immunostaining was also observed in the decidua under artificial decidualization, PPAR $\delta$ expression in decidua may be independent of the presence of the implanting embryos. The data in the present study are consistent with the pattern of PPARס expression in mouse uterus (Lim et al., 1999). PPAR $\delta$ was highly expressed in the decidualized cells under normal pregnancy and artificial decidualization in mouse uterus (Lim et al., 1999). COX-2 expression in mouse uterus also showed a similar expression pattern (Chakraborty et al., 1996). Although there was a failure in decidualization in COX-2-deficient mice (Lim et al., 1997), $\mathrm{CPGI}_{2}$ (a $\mathrm{PGI}_{2}$ agonist) was able to restore decidualization in these mice (Lim et al., 1999). Additionally, targetted knockout of PPARS by homologous recombination resulted in placental defects and frequent $(>90 \%)$ mid-gestation lethality (Barak et al., 2002). Furthermore, RXR $\alpha$ is highly expressed in endometrial cells on days 1-8 of pregnancy (Lim et al., 1999). Abundant expression of RXR $\alpha$ was also reported in the mouse decidua (Mangelsdorf et al., 1992). In the present study, RXR $\alpha$ immunostaining was strongly detected in the decidua on days 7 and 8 of pregnancy. These data indicate that PPAR $\delta$ may also play an important role during rat decidualization through forming a heterodimer with $\operatorname{RXR} \alpha$.

There was a difference in the expression pattern between PPAR $\delta$ immunostaining and mRNA in the present study. Although PPAR $\delta$ mRNA expression was high in the luminal epithelium on day 1 of pregnancy, PPARS immunostaining was not detected. This difference between PPARס mRNA and protein content may result from a post-transcriptional regulation since the PPAR $\delta$ mRNA expression was greater than the amount of PPAR $\delta$ protein. This difference was also noticed in mouse uterus between microsomal prostaglandin mRNA and protein (Ni et al., 2002). However, PPARס immunostaining was detected in the myometrial cells on day 6 of pregnancy, whereas no PPAR $\mathrm{mRNA}$ expression was seen in these cells. Additionally, the PPAR $\delta$ immunostaining in the decidua on day 9 was also stronger than the PPARS mRNA expression. This result may reflect the fact that either PPARS mRNA in these locations has a long half-life or PPAR $\delta$ protein accumulates from other locations.
In conclusion, expression of PPAR $\delta$ was high at implantation sites and in the decidual cells in rat uterus, and PPAR $\delta$ may play an important role during implantation and decidualization as it does in mice.

This work was supported by Chinese National Natural Science Foundation grants 39825120, 30170110 and 30270163, the Special Fund for Major State Basic Research Project (G1999055903), and the project B2-02-02 from National Key Laboratory of Contraceptive Drugs and Devices, Shanghai Institute of Planned Parenthood Research. This work was also funded by CICCR Program subproject CIG-01-64 of the CONRAD Program, Eastern Virginia Medical School, VA, USA. The views expressed by the authors do not necessarily reflect the views of CONRAD or CICCR.

\section{References}

Barak Y, Liao D, He W, Ong ES, Nelson MC, Olefsky JM, Boland R and Evans RM (2002) Effects of peroxisome proliferator-activated receptor delta on placentation, adiposity, and colorectal cancer Proceedings National Academy of Sciences USA 99 303-308

Chakraborty I, Das SK, Wang J and Dey SK (1996) Developmental expression of the cyclo-oxygenase- 2 genes in the peri-implantation mouse uterus and their differential regulation by the blastocyst and ovarian steroids Journal of Molecular Endocrinology 16 107-122

Guan Y and Breyer MD (2001) Peroxisome proliferator-activated receptors (PPARs): novel therapeutic targets in renal disease Kidney International 60 14-30

Gupta RA, Tan J, Krause WF, Geraci MW, Willson TM, Dey SK and DuBois RN (2000) Prostacyclin-mediated activation of peroxisome proliferatoractivated receptor delta in colorectal cancer Proceedings National Academy of Sciences USA 9713 275-13 280

Hatae T, Wada M, Yokoyama C, Shimonishi M and Tanabe T (2001) Prostacyclin-dependent apoptosis mediated by PPAR delta Journal of Biological Chemistry 27646 260-46 267

Kennedy TG and Ross HE (1997) Temporal- and hormone-dependent changes in uterine sensitization for the decidual cell reaction and decidualization in vitro of rat endometrial stromal cells Journal of Reproduction and Fertility 109 129-136

Kliewer SA, Umenoso K, Noonan DJ, Heyman RA and Evans RM (1992) Convergence of 9-cis retinoic acid and peroxisome proliferator signalling pathways through heterodimer formation of their receptors Nature 358 771-774

Lim H and Dey SK (1997) Prostaglandin E2 receptor subtype EP2 gene expression in the mouse uterus coincides with differentiation of the luminal epithelium for implantation Endocrinology 138 4599_ 4606

Lim H, Paria BC, Das SK, Dinchuk JE, Langenbach R, Trzaskos JM and Dey SK (1997) Multiple female reproductive failures in cyclooxygenase 2-deficient mice Cell 91 197-208

Lim H, Gupta RA, Ma WG, Paria BC, Moller DE, Morrow JD, DuBois RN, Trzaskos JM and Dey SK (1999) Cyclo-oxygenase-2-derived prostacyclin mediates embryo implantation in the mouse via PPAR delta Genes and Development 13 1561-1574

Mangelsdorf DJ, Borgmeyer U, Heyman RA, Zhou JY, Ong ES, Kakizuka A and Evans RM (1992) Characterization of three RXR genes that mediate the action of 9-cis-retinoic acid Genes and Development 6 329344

Mano H, Kimura C, Fujisawa Y, Kameda T, Watanabe-Mano M, Kaneko H, Kaneda T, Hakeda $\mathbf{Y}$ and Kumegawa $\mathbf{M}$ (2000) Cloning and function of rabbit peroxisome proliferator-activated receptor delta/beta in mature osteoclasts Journal of Biological Chemistry 275 8126-8132

Matsuura H, Adachi H, Smart RC, Xu X, Arata J and Jetten AM (1999) Correlation between expression of peroxisome proliferator-activated 
receptor beta and squamous differentiation in epidermal and tracheobronchial epithelial cells Molecular Cell Endocrinology 147 85-92

Ni H, Sun T, Ding NZ, Ma XH and Yang ZM (2002) Differential expression of microsomal PGE synthase at the implantation sites and in the decidual cells in mouse uterus Biology of Reproduction 67 351-358

Orlando-Mathur CE, Bechberger JF, Goldberg GS, Naus CCG, Kidder GM and Kennedy TG (1996) Rat endometrial stromal cells express the gap junction genes connexins 26 and 43 and form functional gap junctions during in vitro decidualization Biology of Reproduction $54905-$ 913

Received 3 October 2002.

First decision 5 December 2002.

Revised manuscript received 23 January 2003.

Accepted 24 February 2003. 